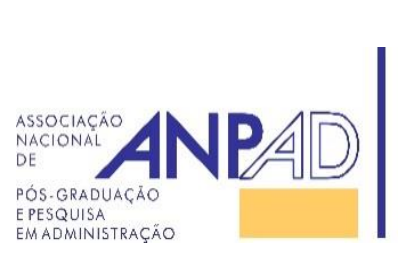

Available online at http://www.anpad.org.br/bar

BAR, Rio de Janeiro, v. 13, n. 4, art. 3, e160081, Oct./Dec. 2016

\title{
Inked Careers: Tattooing Professional Paths
}

Gabriela DeLuca ${ }^{1}$ Sidinei Rocha-de-Oliveira ${ }^{1}$ 


\begin{abstract}
The concept of career has an interdisciplinary and historical constitution, which includes persons, groups, organizations and society. Given that, we aim to deepen the interactionist notion of career from the understanding of a deviant path, supported by a theory and a method appropriated to the cited call for interdisciplinary approaches. Dilemmas (Hughes, 1958) and conflicts (Hughes, 1937) emerged as important analytical categories. Although necessary, these two concepts were not sufficient to contemplate analyses in their entirety. For this reason we conceptualized a third possibility of controversy during a career: the inquiries. The study followed the Narrative method to analyze objective and subjective changes during a tattoo artist's career through interviews and informal conversations carried out over 22 months. The discussion presents three main contributions. Theoretically, a new understanding of the concept of careers, linking past, present and future and the idea of non-linearity of experienced and envisioned careers. Methodologically, suggesting orientations for future career studies such as the use of turning points as a methodological tool and the investigation of deviant fields. Finally, our defense of the interactionist perspective as suitable for career studies, since it allows the investigation of deviant elements.
\end{abstract}

Key words: careers; deviant careers; symbolic interactionism; tattoo; narratives. 


\section{Introduction}

The concept of career has an interdisciplinary and historical constitution, which includes persons, groups, organizations and society, showing a dynamic interaction between the subjects and the world around them, since "the career is viewed as an outcome not only of individual attributes but also of both organizational and historical contexts" (Grandjean, 1981, p. 1057). Despite the expansion of the discussion on the topic, there is still a call for greater interdisciplinarity (Arthur, 2008; Chudzikowski \& Mayrhofer, 2011; Khapova \& Arthur, 2011; Lawrence, 2011) to renew the research field and offer advances in theoretical and methodological discussions. These callings require the use of different theoretical and methodological perspectives as well as the exploration of new research contexts.

The first leads to the resumption of the career understanding by Symbolic Interactionism, which allows interdisciplinarity, analyzing careers using both objective and subjective aspects (Hughes, 1937). The latter leads to the search for less bureaucratic occupations (Grandjean, 1981), envisioned as a fertile ground for the discussion of concepts, methods and expansion of empirical material. As Grandjean, we understand bureaucratic occupations or careers as the ones organized by established and accepted rules of entrance, criteria for promotion and success and explicit lines of career progression. As examples of researches beyond bureaucratic occupations, we point out Hardy and Sanders' (2015), exploration of strippers' work in the UK, Burrow, Smith and Yakinthou's (2015) description of a chef's career in the fine dining industry, and Simpson, Hughes, Slutskaya and Balta's (2014) exploration of butchers' values in dirty work.

Interested in deepening and expanding the understanding of careers conceptually and practically, we aim to investigate a deviant research field, supported by a theory and a method appropriated to the cited call for interdisciplinary approaches. By deviant we do not mean criminal. Instead, we use Becker's concept of deviation (2008), as the ones who break mainstream social rules - whether they are legal or social. In this sense, we understand tattoo artists as an interesting field, since they can be labeled as deviant. On one hand, these people were labeled in Western history as deviant, marginal, criminal, rebellious and wild, which presupposes the relevance of its analysis regarding the notion of deviation (Becker, 2008). On the other hand, their occupation does not yet carry a professional status (Hughes, 1958), although these tattooists understand themselves as professionals. In this sense, deviation is our concept as opposed to bureaucratic.

Existing work about the theme explored the practice's history in the Western world (DeMello, 2000; Oliveira, 2012); the consumption of tattoos (Araujo, 2005; Ferreira, 2004) and their acceptance inside labor markets (Timming, 2015); the link between tattoo and deviation (DeMello, 2000); the impact of visible tattoos on employment chances (Timming, 2015) and between tattoo and art (Kosut, 2006); management practices inside studios (Timming, 2011); and the link between the tattoo artists and their occupation (Ferreira, 2012; Maroto, 2011; Oliveira, 2012).

As an occupation that apparently has not reached the status of a profession, tattoo artists might be an exciting field of research and understanding careers. The analysis of an occupation becoming a profession can clarify the ways in which the profession influences and is influenced by people in a reciprocal relationship between social action and social structure (Hughes, 1958). That is the reason why, despite the large scope of what the interactionist notion of career includes, this analysis is focused on the objective and subjective aspects linked to people's occupations - in this case, tattooing. As opposed to being limiting, the analysis goes further, comprising such a profession as under development. In this sense, we take the tattoo occupation as our empirical field, using occupation (Hughes, 1958) as our main concept, even though there are other analytical categories possible, such as creative work and gender.

Thus, we seek to understand how the career of one tattoo artist, named Heraclitus, is experienced from the ties established by him with his daily activities, his workspace and his memories, through interviews and informal conversations carried out over 22 months. The objective is to deepen the interactionist notion of career from the understanding of a deviant path, contributing throughout 
an interdisciplinary analysis allowed by the interactionist perspective, with theoretical and methodological contributions for future research. In addition, this work aims to contribute to theoretical discussion about careers in Brazil, joining works like Silva, Balassiano and Silva (2014) and DeLuca, Rocha-de-Oliveira and Chiesa (2016).

To achieve this, dilemmas (Hughes, 1958) and conflicts (Hughes, 1937) emerged as important analytical categories to understand his career. Although necessary, these two concepts were not sufficient to contemplate the analyses in their entirety. For this reason we conceptualized a third possibility of controversy during a career: the inquiries.

The article is structured into seven parts, including this introduction. The theoretical framework is based on Symbolic Interactionism, mainly with Hughes' career concept (1937), dilemmas (Hughes, 1958) and conflicts (Hughes, 1937). Then, we detail the method used, which is Narratives (Riessman, 2000). Both theory and method are adopted from a process perspective. Then, we present a spatiotemporal context, followed by the presentation of Heraclitus' life narrative. Finally, we discuss the theoretical aspects of the narrative, followed by our final considerations, in order to point out this research's main theoretical and methodological contributions, as well as future research possibilities.

\section{Theoretical Background}

Career studies integrate a diversity of theoretical fields, although in the last two decades a concentration of discussions is noted around the concepts of protean career (Hall, 1996) and boundaryless career (Arthur, 1994). As a result, there is a search for generalization of the way professional careers are built and a lack of interdisciplinary analysis (Inkson, Gunz, Ganesh, \& Roper, 2012; Sullivan \& Baruch, 2009).

Given the aforementioned call for interdisciplinarity in career discussions (Arthur, 2008; Arthur, Hall, \& Lawrence, 1989; Khapova \& Arthur, 2011; Sullivan \& Baruch, 2009), the criticism of the dichotomy established between the individual and the institution and between process and structure (Moore, Gunz, \& Hall, 2007) and the possibility to research occupations that are different from established ones (Anderson, 1923; Becker, 2008, 1951), a theoretical basis was needed that would allow an alternative to transpose such limitations. Therefore, the resumption of Everett Hughes' interactionist perspective seemed to be an opportunity to discuss careers in a more dynamic manner.

Everett Hughes was a sociologist from the Chicago School, which was also the birthplace of Symbolic Interactionism (SI) in the early twentieth century. SI has as a premise the understanding that person and society are inseparable and interdependent units. The interactionist vision believes that meanings emerge from social interaction and, going through the interpretive process, constantly establish themselves and change. Blumer's premises (as cited in Fine, 1993) of SI include that objects are known by their own meanings, which are created and modified through social interaction (Fine, 1993). Because of the possibility of multiple interpretations, according to the adopted point of view and according to space and time, SI differs from an apparent positivism, since it is not possible to predict or determine what is true per se - since the social fact is located (Abbott, 1997). The location of a social fact requires space and time context for the analysis of the sociological event (Abbott, 1997). It also relativizes the view from the investigated subject, adding the subjectivity of the person or community to the contextual objectivity.

To clarify this dynamic perspective it is necessary to remember and punctuate its epistemological starting point: William James, John Dewey and Herbert Mead, who are understood as Process Philosophy writers (Helin, Hernes, Hjorth, \& Holt, 2014) and are the key influencers of SI (Barley, 1989). Their concepts contribute the need to keep in mind the fundamental nature of fluidity and interaction. In this sense, Everett Hughes' way of thinking carries a notion of unity, especially in his notion of career: "a career is the person's sequence of role and realized status and office" (Hughes, 1937, 
p. 404), i.e. the career is understood as a person's life as a whole. Thus, the duality, especially involving status and roles is apparent. They are used as didactic and analytical categories.

The career understanding used in this article involves all aspects of one's life, as well as his occupation, addressing issues that Hughes called objective and subjective. Objectively, a career is a "series of status and clearly defined offices" (Hughes, 1937, p. 409), status being already accepted social categories (Hughes, 1937). Subjectively, "a career is the moving perspective in which the person sees his life as a whole and interprets the meaning of his various attributes, actions, and the things which happen to him" (Hughes, 1937, pp. 409-410). Therefore, a career is a fluid combination of objective and subjective aspects through which one passes, interprets and conceives his or her identity. This fluidity emphasizes its interactionist background.

When the person experiences different social contexts, including different types of groups, he or she may experience conflicts (Hughes, 1937) and/or dilemmas (Hughes, 1958). Conflicts occur when subjective and objective aspects come into contradiction. The person experiences a struggle. Therefore, the result tends to be a decision between the aspects: the person chooses one or another. The dilemma would be the contradiction between objective aspects (Hughes, 1958), a clash of social statuses such as someone who is marginalized by his or her color, on one hand, but occupies a high social position, on the other (Hughes, 1958). The consequences here tend to be structural reorganizations in institutions and one's own negotiating processes, varying according to the type of society in which he or she lives.

Therefore, the interactionist perspective allows the use of deviant occupations in theoretical and empirical studies, since its concept of careers is established from the individual, and not structural, perspective. In this sense, we are not limited to legalized or institutionalized professions.

According to Becker (2008, p. 35), "career is a useful concept in the development of sequential models of various type of deviant behavior". The author named it deviant careers, although his Chicago colleagues had already coined the term, understanding that "to have a deviant career was thus tantamount to being socialized into the ways of a subculture" (Barley, 1989, p. 44) subtly differing from each other. Both, however, rely on analysis of the perception of typical stages through which people undergo, formed by turning points that make deviant individuals follow a particular path or not.

Although deviation is not an analytical concept here, we understand its importance to justify our empirical field, as well as our method. The use of turning points is suggested as a tool for the Narrative method, as we will explore next. In addition, understanding deviant careers (Becker, 2008) helps to broaden discussion of the concept of career and its shortcomings, since it is not limited to bureaucratic occupations.

In short, the understanding of career embraces a singular whole to one person (Hughes, 1937), who while interacting with social space influences and is influenced by institutions (Hughes, 1958). Moreover, it also changes according to the type of society (Hughes, 1937), group (Barley, 1989; Becker, 2008) and spatial and temporal context (Abbott, 1997) in which the person lives. Didactically, a career is understood as including objective and subjective aspects of a person's life (Hughes, 1937, 1958), which may cause a conflict (Hughes, 1937) or a dilemma (Hughes, 1958) during the experiences and interactions with groups, professions and institutions. With this conceptual overview, the primary intention is to strengthen the interactional, relational and contextual idea of interactionist concepts (Abbott, 1997; Barley, 1989).

\section{Methodological Framework}

Qualitative methods, such as Life Story, are influenced by anthropological perspective (Barley, 1989; Becker, 1997). In addition, we took an interpretative methodological orientation, as followers of Diltheynian Verstehen (Abel, 1948; Simmel, 2011). This perspective advocates the search for understanding the subject, from his or her point of view (Herva, 1988). From this methodological 
background, we used the Narrative method (Riessman, 2005). Biographical narratives allow the investigation of objective and subjective changes during a career (Domecka \& Mrozowiki, 2005), without commitment to a verifiable reality, but rather with the meanings given by the person who tells the story (Bruner, 1991). Its main feature is to allow interviewees to be free to tell their narrative, because people give meaning to their lives (Domecka \& Mrozowicki, 2005) and build their reality (Bruner, 1991) throughout narratives. In this sense, Narratives appear to be an appropriate method for Chicago's interactionism, contemplating objective and subjective aspects of the individual's life.

The following presentation is about the life narrative of Heraclitus, a 34-year-old tattoo artist living and working at his own tattoo studio in Porto Alegre, the capital of the state of Rio Grande do Sul in southern Brazil. There, we established contact with other people that worked at, visited or were tattooed at the place for 22 months beginning in 2013. The main sources of collection were three Narrative Interviews (Riessman, 2000, 2005) conducted with Heraclitus himself at the end of 2014. Beyond these, there were another ten interviews with other people somehow related to him and/or relevant to the tattoo industry in the region. In addition, the 22 months observing and documenting the studio, regional and national conventions served as an empirical source, guided by Participant Observation. In this sense, we took ethnographic techniques to complete our empirical sources. As Van Maanen (2015) points out, understanding career as a variable pattern, "it is best and most faithfully evoked and made visible through lengthy, hard-slogging fieldwork alongside those who enact the career" (Van Maanen, 2015, p. 47).

In order to integrate the understanding of time and space (Abbott, 1997) in which the narrative occurs, we also carried out a historical document research on tattooing in the West, in Brazil and in Porto Alegre. For reasons of focus and page limitations of this paper, we only briefly present the historical overview. Also, we deliberately focus on Heraclitu's interviews, even though the others cannot be neglected. Supported by the interpretative method, we understand that one's life history may represent others (Denzin, 1984). Finally, for the same page limitation reasons, we present Heraclitu's narrative in our own words. Even though it is possible to present the narrative completely in the way the subject narrates it (Burrow, Smith, \& Yakinthou, 2015; Eikhof \& York, 2016), results are still interpretations by the narrator, the researcher and the reader.

Interviews and field diaries were transcript and analyzed using N-Vivo as a support tool. The analysis followed thematic and structural orientation (Riessman, 2000, 2005), appropriate to the narrative form of the interviews. In this sense, categories, turning points and life periods emerged from the field. The analysis proposed by Riessman (2005) relates to the theory and object of study, since it assumes a plurality of truths in the links between individual and collective spheres and the analysis of disciplines including professions (Riessman, 2000) and career studies (Burrow et al., 2015).

Next, we present Heraclitus' narrative, preceded by a brief historical background of Tattoos. As an interactional narrative, this location of the event (Abbott, 1997) is necessary. Heraclitus' story is singular; but his singularity can be universal (Denzin, 1984). Due to the nature of this work, the history of Tattoo is summarized and we recommended a selected bibliography for a more in-depth understanding.

\section{Space and Time in Heraclitus' Narrative}

Tattooing's journey can be traced to prehistoric times. Its perception transformed along the way: pagan, wild, marginal and artistic (DeMello, 2000; Ferreira, 2004). Pagan before the Navigation period, from the visit of Captain James Cook to the Pacific it was labeled as wild and named: tattoo. The meeting of East and West took tattooing to the cities, especially the suburbs, in the so-called freak shows, in which tattooed people were circus attractions. In the twentieth century, it became a symbol of crime and rebellion. In recent years, it is gaining art status, helped by democratic Internet advocacy (Kosut, 2006). 
In Brazil, the formation of a group of professionals took place through travelers, who accompanied foreign vessels, crime or marginal life. It became centered on one man: Lucky Tattoo (Marques, 1997), a tattoo artist established in Santos in 1959. By being associated with travelers, the first studios settled in port cities like Santos, Rio de Janeiro, Florianopolis and Porto Alegre.

In Porto Alegre, it became widespread in the late 1980s, with four major names: Frank, Edu, Lagarto and Verani. These pioneers were part of the first generation of local tattoo artists. These men passed their knowledge to others, resulting in the second generation of tattoo artists, which includes Heraclitus, an apprentice of Verani. During this period, the market was still limited, requiring courage for the person to move forward on the path even with the strong stigmatization of that time, the media and inaccessible labor resources. Therefore, technical training took place through direct and personal contact and within the tattoo studios. A period of little hygienic and artistic rigor, and prone to the emergence of a small group and close relationships - just like a family.

From the 2000s on, there was a boom that disseminated the practice and also contributed to increased regulation, particularly in the working tools and rules (Resolução $R D C n^{\circ} 306,2004$; Resolução $\left.R D C n^{\circ} 55,2008\right)$, and greater access to consumption and practice. The emergence of the specialty materials industry for tattooing seems to have profoundly influenced the field, including the learning modes. However, the activity is not yet regulated. The regulation of studio practices, resulting in paid taxes, and the lack of regulation of the profession, which would result in personal security, emerge as inquiries from the field, opposed to the state regulators. In this sense, there is a group effort supporting a law project in this regard (Projeto de Lei s/n., 2007; Projeto de Lei $n$. 1444 de 2007, 2013). Thus, many people work unregulated, legally, or informally, in discord with the rules established socially inside the group that license behavior (Hughes, 1958). In addition, the 20-year-old youth group from 1980 is now aging and began to imagine a future of retirement, which is currently non-existent. So for the past two years, the group has organized an association composed of tattoo artists and body piercers intent on professional organization and demanding regulation of the activity.

The labor market of this occupation can be seen as heterogeneous (Bucher \& Strauss, 1961). There is both an internal division among both older and younger as among the types of work and techniques developed by each person, especially between commercial and artistic tattoos. This division, however, does not result in objective divisions, limiting positions, status or roles. In one sense, everybody is a tattooist, changing only added labels such as tattoo artists, commercial tattooists, informal tattooists, master tattooist, and so on. Differences between offices exist based on development or the type of tattoo they produce, and not by hierarchical or financial differences.

Briefly written, this is the scenario within which Heraclitus comes across and by which he was also influenced. As an interactionist narrative, this location of the event (Abbott, 1997) allows presentation of this tattoo artist's career narrative.

\section{Heraclitus: drawing a life path}

Heraclitus turned 34 in 2014, with 14 of these years dedicated to tattoos. The tattoo artist has a nationally renowned studio, winning awards at conventions and a portfolio full of realistic work, which is considered a more refined tattoo technique. Luckily, as he says, the tattoo market has changed a lot since its beginnings, making tattoos and tattooists less stigmatized compared to 15 years ago.

Heraclitus narrates that his choice for tattooing began with childhood drawings, a period marked by the habit of drawing and painting under the influence of his grandmother. His memories of drawing during his childhood emerged as an important landmark, having been reported by all interviewees, each one differing in what kind of art they used to do. His coherent recollections are part of the conception of the narrative, since the person who narrates accounts for what makes sense for his or her current state (Velho, 2006).

Heraclitus continues to experience drawing, testing it on different surfaces. The idea of experimenting on skin starts driving the direction for his future occupation - although the person has 
not transposed the courage barrier yet (Becker, 2008). For this, the support of someone, usually a relative, seems crucial, since "the young rarely has, a priori, as an aim of life to become a tattooist" (Ferreira, 2012, p. 85). As Heraclitus grew older, his father appears in his narrative as a crucial figure, as a stimulus to follow this path: "my father supported me, my father supported me with this thing. He said 'listen, why don't you tattoo people?".

In his teenage years, Heraclitus crossed social barriers, buying his first materials and tattooing friends in his bedroom, a practice narrated also by other people. Because there is no college degree for tattooing, they developed their early learning as amateurs. It was a time when, as a small industry and a limited market, people would serve as guinea pigs. Due the little information they had, they could not properly judge the quality of the work.

Heraclitus highlights the dedication to his activities and his hunger for always doing better. This way of thinking about work marked a technical development period and is reflected in the improvement of his tattooing practice. At a time without the Internet and with a limited industry, he sought information and places to practice his technique observing the work of others in person and through magazines:

"I bought magazines and I could see other people's work, I could use them as reference. Because I saw beautiful tattoos and started to think 'how did they make this? There were no training courses, nothing. If they made it, so can I'. Then I had to try and do what the person did.... that is how I developed my technique. Then you make that so many times in a month ... that you ... store that [the procedure] as a file in your head." [Excerpt of an Interview with Heraclitus].

Even with the observations, the practical knowledge with guinea pigs is critical and remained throughout this period. The continuity of this path of insertion and learning is interrupted by a conflict (Hughes, 1937). Heraclitus knew he was no longer amateur, subjectively, but also knew he as not recognized as a professional, objectively. Not only because there is no profession as tattooist in Brazil, but also because he was not tattooing inside a studio - which could brand him for the tattoo market. The conflict, therefore, is between a subjective aspect, that is, to see yourself as a tattoo artist, and the objective aspect, that is, to not be seen as a tattoo artist. As Hughes (1937) points out, the result of a conflict can mean a radical change in one's path, as it is necessary to decide between staying in his occupation or moving on to another. Those who choose to continue the tattoo practice realize that they must enter the family - an idea that represents the importance and strength of personal relationships in this occupation. For that, the person must leave his or her room and start tattooing people beyond close friends. He or she needs to enable a network of relationships and seek a tattoo studio to work.

Meanwhile, at around 18 years old, Heraclitus also considered a bureaucratic profession: Dentistry. He tried to enter a university three times, giving up after the last one. With that, Heraclitus sought a job at the studio where he bought materials and, after being refused, found a place to work in his aunt's beauty salon. At this time, Heraclitus already had some of his work circulating in the market. After a few months in this situation, he received a call inviting him to work as an assistant in the tattoo studio that he had pursued before, replacing an employee on vacation.

Single and childless, the work in this studio gave Heraclitus the opportunity to focus on his tattoo studies. From morning to night, he studied drawing and tattooing, always enhancing the seriousness with which he treated his work. The 10 years he stayed in this studio served to develop his technique, to the dissemination of his work and name, and the formation of a broad network of relationships. Beyond the financial gain, the pursuit of learning is guided by the goal of developing a technique and a specialty in the tattoo field.

However, the pregnancy of his ex-wife made Heraclitus think about the future again, motivating him to take other paths. From this, one may or may not come across a dilemma (Hughes, 1958) or a conflict (Hughes, 1937). A dilemma, being recognized as a tattoo artist, a commercial one or an artisan, depending on the observer; or a conflict between social roles that one sees fit as a good father and the statuses that oppose themselves as a low paid tattoo artist. 
For Heraclitus a conflict emerged between his status as a Tattoo Artist-Craftsman and his emerging role as a father. The conflict resides in the need, according to Heraclitus, to have more financial income to support a family, a prospect that he did not have before. As pointed out, a possible result of the conflict is a change (Hughes, 1937). Heraclitus chose to leave the studio he was working. Such a decision, contrary to what the reader might interpret, did not destabilize the ties he had established with his colleagues and master.

Heraclitus already had a technical level that allowed him to consider professional autonomy - he was a tattoo artist-craftsman - and chose to also be a tattoo artist-entrepreneur, opening a tattoo studio with his name. This decision also contemplated a previous and reminiscent inquiry about the studios he was observing. For him, many studios were negligent about the technique of their tattooists. Thus, his subjective understanding of what it means to be a professional tattooist did not match with the studios' concepts of the same.

Heraclitus and three other tattoo artists would give life to his first studios' team. The responsibility of having a business allowed him to form a team with his own principles, sharing his technique, and the possibility of increasing his income to support his family. However, it expanded his responsibilities beyond his own work, reducing his time for study and development of his art.

In the last two years of this study, Heraclitus started to develop more tattoo work with his team, from daily practices drawn according to his judgment. Gradually, he established a highly regarded team, now with 11 people, which seeks to improve their work more and more - as a result of Heraclitus' mentality.

Today, Heraclitus goes through physical challenges arising from recent tendinitis in his right hand. This obstacle to work raises the issue for the need to regulate the activity, which would provide government aid in case of illness or accidents. Faced with limitations, Heraclitus has sought to resume drawing and painting studies, traveling regularly, reliving his desire to be a painter, as recalled in recent interviews and conversations.

As he is in a time of reflection on his career, it is difficult to see what will be his next steps, but it may involve workshops, for which he has been invited to teach in the last year, in a period of maturity of his professional experience. According to him, "I'd be a teacher". In fact, he has already been regarded as a reference and instruction source in these workshops and the master and apprentice relationships that are established inside his studio.

\section{Discussion of a tattooed path}

First, we need to clarify the didactic and comprehensive nature of this work and its reflections. In fact, the unfolding of this narrative can demonstrate the history of many others. The process perspective allows for this: even though there are singular contents, it is possible to understand a form that is generalized. It seems that the theoretical approaches to career subsumed to the interactionist perspective understand it as a series of events and experiences related to one other, in which the same event is cause and consequence (Simmel, 2011). Hughes (1937) does not assume linearity in careers and the so-called deviant careers seem to be like a zigzag (Boylstein \& Maggard, 2013; Meisenhelder, 1977), going repeatedly through diverting labels (Becker, 2008). The format of a historical and chronological series, visible when the person narrates his or her life history, is only possible to be related to past phenomena. Thus, the career can be outlined based on the relationship between past, present and future, as shown in Figure 1. 


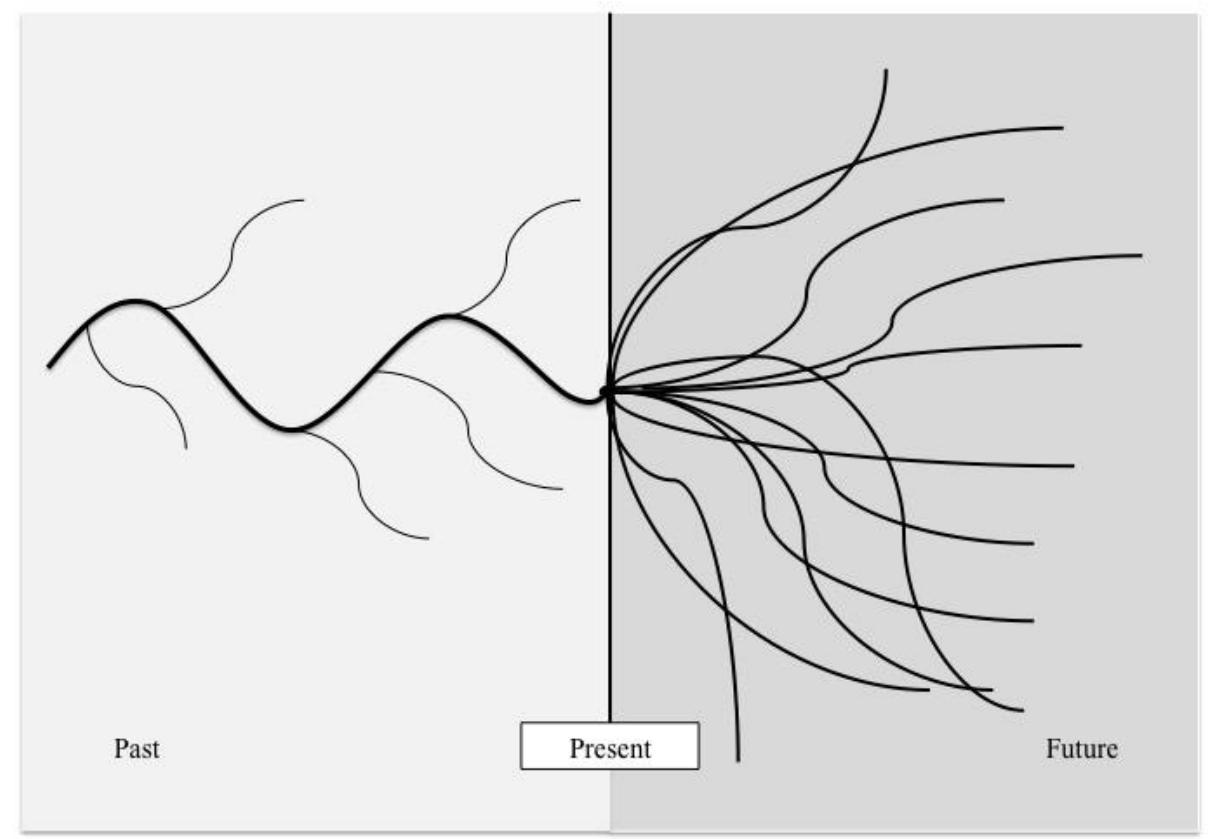

Figure 1. Representation of Contemplation of the Past and Future by the Subject

The darker line in the left quadrant called past is a memory that makes sense to the present state, at the center of the image. This line tends to be the narrative chosen by the individual to tell. Even if the person sees possibilities that have not been experienced - represented by loose, weaker lines, also in the past - he or she realizes and tells a stronger line corresponding to the experienced path. While past events do not change, they are reinterpreted from the present moment and can thus be changed in their order and narrative to make sense to the current state. The unfinished lines represent the possibilities of the professional career at each turning point, but which are still narrated, demonstrating an abandonment, yet not definitively, of these alternatives. For example, Heraclitus, at times, remembered his desire to be a dentist. In others, specifically in the last conversations, he recalled the desire to be a painter. The difference in those memories (desire to be a dentist and a painter) shows the meanings of the past in the present, reinterpretations of his career up to the present, as before he was focused on his technical development as a tattoo artist. In this sense, there are many social facts that really happened, sum to the individual deliberating on memories, which choose and transform these social facts.

The mentioned turning points can be understood as decision points. At these points, there appear to be strong influences of family members in career choices, not only in this first decision during adolescence but also in the professional experience (Becker, 2008), for decisions between one or another specialty, for example, and one status or another, as commercial or artist - as in the case of jazz musicians (Becker, 2008; Umney \& Kretsos, 2013). In the case of Heraclitus, his grandmother and father, at the beginning of his path, as well as his son, emerge as influential elements. Family support or a close person support helps to overwhelm the decisive barrier (Becker, 2008) to move on. Thus, it seems that dilemmas (Hughes, 1958) are solved with the support of such elements.

Thus, these turning points also represent dilemmas (Hughes, 1958) conflicts (Hughes, 1937), and what we are calling here inquiries, which are experiences soon after making a decision to change or stay on course. Although Hughes proposes that conflicts and dilemmas culminate in individual and social changes, the author does not consider them as a methodological tool, although it was shown that they could be used as a tool to understand a career.

On the right quadrant of the figure, called future, there is a glimpse of the future trajectory from the present time. Multiple possibilities exist in this future path not yet taken, from which the person will choose one and will find new meanings to it along the way, as with the current ones. Considering 
Heraclitus' path, today he is experiencing a subjective reflection, a conflict imposed by the limitation caused by tendinitis and his current work possibilities.

By analyzing the figure in its entirety, a career can be understood as a tangle of non-dichotomous dualities, as reciprocal interactions that become a unit, which include collectives and individuals, fields and relationships, intersections and ties, past and future. One contemplates institutions, groups and others, and also interacts directly with them, questioning and changing them. That is the reason to consider social space-time location, as it will influence judgments and personal decisions, and is part of an interactionist analysis (Abbott, 1997). Thus, one considers it in its entirety to understand life itself. This understanding may point to deeper theoretical and methodological reflections, in referring to the pioneering discussions of the human sciences in the nineteenth century, which had the processual thinking on understanding (Verstehen) (Simmel, 2011) as its own alternative to the social sciences.

Heraclitus' relates to the last 20 years of the tattoo consumption and work market in Porto Alegre, as well as the stories of others. His career is marked by contextual elements, such as greater acceptance of tattoos, expanded use of new technologies - such as the Internet and more modern tattooing equipment - and greater knowledge and demand from customers, which increases the accuracy of the technique and the development of two understandings of the work. All of these are part of a culture inscribed in the group, interfering in understanding individual careers. Heraclitus is also considered one of the people responsible for transforming the market in Porto Alegre, which shows his influence in the social sphere.

The career narrative features steps, which are separated by inflection points (Riessman, 2005), or called turning points, perceived as more prominent in this trajectory. These steps were highlighted by the expressions in bold for the account of the previous section. In each of these steps, it is possible to experience uninterrupted processes of the professional life, which can build up throughout its duration - going on with varying intensity depending on the path.

In Figure 2, the professional career is represented with these stages, with the methodological aim of analyzing its objective and subjective aspects. The centered line, with black circles, is the life story of a tattoo artist, since its inception, at the top of the image, to the present day, at the bottom of the image - in which several future possibilities are represented in the future. The career turning points, represented by circles in the center line, can be characterized in its intermediation by a salient experience of the process in the time range - to the right of the image. Thus, the improvement of technique and the experience in the tattoo family tend to start respectively in the artist's childhood, becoming more salient as the artist crosses social barriers of amateurism. These processes remain throughout the trajectory of the person when he or she chooses to remain in the tattoo industry. Some moments are represented by solid lines, in contrast to the dotted lines, less relevant to the experience in that moment of life. 


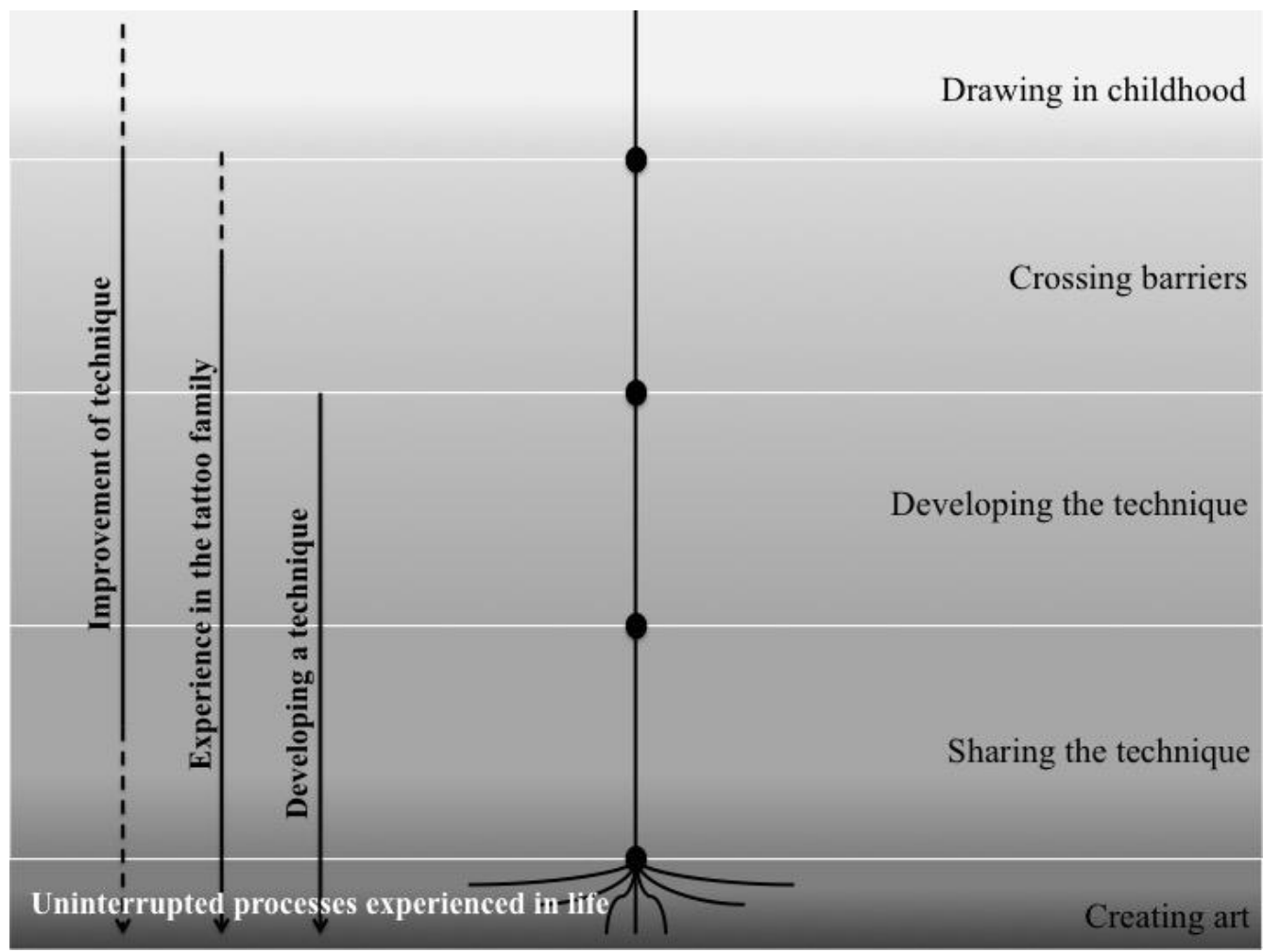

Figure 2. Graphical Representation of a Tattoo Artist Career Trajectory

Thus, while discussing careers, the turning points are critical since they represent (a) methodological analysis resources for the trajectory of a person within a professional field; and (b) negotiation processes between individuals and their possibilities (2006), permeated by conflicts (Hughes, 1937), dilemmas (Hughes, 1958) and inquiries.

First, as a methodological resource, the points can be understood as reflection milestones, usually resulting from experienced conflicts, dilemmas and inquiries. When realizing that the careers of different people who work in a particular area go through the same turning points, this may be the way of forming a standard career (Hughes, 1937), defining periods of formation of experience, conversion and socialization (Hughes, 1958).

Second, these elements underlie the conflicts, dilemmas and inquiries that a person experiences, which result in changes in one's individual life and, over time, can result in changes in status, offices and institutions of an occupation. It is worth mentioning at this point the uniqueness between personal and professional life in career directions and this intersection is linked to conflict or dilemma that leads one to the next step inside or outside one's field. In addition to the conflicts and dilemmas, as contemplated by Hughes $(1937,1958)$, as the reader may have noticed, another group of possible points of reflection to be considered appeared, which were called inquiries in this research. Inquiries would be clashes between objective or subjective aspects of life with the institutions one goes through - in this case, a tattoo studio and legislation, among others.

It is also worth mentioning that the analytical separation performed above represents processes that are integrated, showing that a career will be a life experienced, in which all these elements are fluid and interconnected. In this sense, the sum of status and positions and social roles, as pointed Hughes (1937) can, to some extent, represent a career. 


\section{Final Considerations and Main Contributions}

This article intended to present a career narrative, focusing on the non-institutionalized occupation of the narrator, to understand the notion of career in an interdisciplinary and non-structural way. The theoretical and methodological choices were made following these assumptions, as appropriate to the field under study. The final considerations, then, are based on this goal: to deepen the interactionist notion of career from the understanding of a deviant path. In this sense, we detail (a) theoretical and (b) methodological contributions, and (c) suggestions to clarify the contributions of using the SI perspective. At the end we present limitations and suggestions of future research.

First, theoretically, we presented a new understanding of the concept of career, as already mentioned in this article: A career can be understood as a tangle of dualities, as reciprocal interactions that become a unit, which include collectives and individuals, fields and relationships, intersections and ties. One contemplates institutions, groups and others, as one also interacts directly with them, questioning and changing them. Thus, one considers it in its entirety to understand life itself.

It is necessary to adopt a proper attitude, as researchers, before exploring social objects of study. The interactionist perspective includes reciprocity between individual and collective aspects, since one adopts a view that understands separations as didactic tools, but not as mirrors of reality. Hughes (1937) regards that a foreign stance, as the author describes the figure of a sociologist, includes placing oneself outside the studied sphere, but also inside it. This means that in addition to contextualizing space and time (Abbott, 1997), one must adopt the point of view of the subject, as part of their group, but also move away from it to see the mosaic of their life and society as a whole.

Adopting such a stance, we ask the reader to do so, in order to better understand the three theoretical contributions: a new understanding of the concept of careers, cited above; the link between past, present and future, linked to the idea of non-linearity of experienced and envisioned careers; and the importance of considering conflicts, dilemmas and inquiries, the latter an original contribution of this study.

The link between past, present and future understands that although the past has already been lived, it is continually reinterpreted. The future looks diffuse and reflected in the present moment and in re-signified memories, which allows one to reconsider abandoned alternatives. This understanding takes career as a non-linear sequence (Boylstein \& Maggard, 2013; Meisenhelder, 1977), in constant transformation - even its past. In addition, a look at the past and future allows us to acknowledge turning points. Dilemmas (Hughes, 1958) and conflicts (Hughes, 1937) take on a new perspective when tied to turning points, as they seem to be narrated according to path decision points. Besides these, we specified a third controversy - the inquiries, which would be the contradiction between subjective or objectives aspects in relation to institutions with weaker links to a person. This set features an analytical tool for understanding an individual career and training for a profession, allowing scores of experienced similarities.

Second, methodologically, this research enables suggesting three orientations for future career studies: the use of longitudinal studies; the use of turning points as a methodological tool; and the investigation of deviant fields. Longitudinal studies, like this, enable the researcher to understand the dynamism and changes in a life path. This longitudinal study enabled further research as a result of immersion in the field and proximity to the interviewees. Such an approach in career studies allows the researcher to see the changes over time, and enable the vision of transformation in an expanded sense in groups, organizations and institutions. While exploring turning points, they contribute in three ways: (a) they serve as a methodological resource, allowing a schematic analysis and enabling us to trace similarities between different trajectories and clarifying dilemmas, conflicts and inquiries experienced; (b) they become objective landmarks for the person who narrates and are points of transformation into a standard career or a profession; and (c) they transpire negotiation processes, permeated by conflicts, dilemmas and inquiries. Added to the Narrative methods is the use of turning points which are not fixed, 
but emerge from the subject's narrative. All these characterizations may be included in an ethnographic perspective, since "the logic [in career studies] is one of discovery, not verification. Thus, a plea to career researchers of all sorts to be attentive to what we organizational and occupational ethnographers have to say" (Van Maanen, 2015, p. 47).

As mentioned, deviant fields clarify the social interactions and reciprocity between individual and groups, institutions and organizations. In this sense, deviant fields can be taken as a methodological strategy to contribute, theoretically, to career studies and, in practice, to disseminate its peculiarities and organizations, even for public policies.

Third, we presented the contributions of the SI perspective. In theory, the interactionist perspective is suitable for career studies, and allows the investigation of deviant elements, which amplify its understanding beyond bureaucratic careers. As pointed out by Mayrhofer, Meyer and Steyrer (2007), it also includes the contextual aspects - even as they present their own challenges - agreeing with the notion that "careers are always in context" (p. 215).

Finally, such understanding requires deeper reflections, both theoretical and methodological. In this sense, the so-called interpretative perspective might be a possibility of epistemological lenses, from the peculiar guidelines for human sciences by Simmel (2011) - highly influential in the Chicago School (Barley, 1989). Its sociological and philosophical processual perspective understands the dualities as joint units, to meet the will to overcome the dichotomies between the named macro and micro levels. In addition to that, the terms profession and career presented in this work, if looked at with the right lenses, already cover the substantial reciprocity between individual and individual, individual and collective and individual and organization. Finally, even though we took tattooists as deviant, we understand that this field is complex enough to contemplate other analytical perspectives, as embodiment careers (Coupland, 2014) and creative work (Platman, 2014; Siebert \& Wilson, 2013; Umney \& Kretsos, 2013), just to mention two.

As a watercolor, careers seem to transform at every stroke, even if the risks, spots or blemishes have been done. Just like a painting, different colors form a single whole, which allows the researcher to have a glimpse and make sense of the phenomenon. Like an elaborate technique, it requires study, learning and persistence. Therefore, jobs that follow the theme in deviant fields, seeking different perceptions may add and interbreed understandings that will contribute to an interdisciplinary and colorful understanding of careers.

\section{References}

Abbott, A. (1997). Of time and space: the contemporary relevance of the Chicago School. Social Forces, 75(4), 1149-1182. http://dx.doi.org/10.2307/2580667

Abel, T. (1948). The operation called Verstehen. American Journal of Sociology, 54(3), 211-218. http://dx.doi.org/10.1086/220318

Anderson, N. (1923). The hobo: the sociology of the homeless man. Chicago, IL: University of Chicago Press.

Araujo, L. (2005). Tatuagem, piercing e outras mensagens do corpo. São Paulo: Cosac Naify.

Arthur, M. B. (1994). The boundaryless career: a new perspective for organizational inquiry. Journal of Organizational Behavior, 15(4), 295-306. http://dx.doi.org/10.1002/job.4030150402

Arthur, M. B. (2008). Examining contemporary careers: a call for interdisciplinary inquiry. Human Relations, 61(2), 163-186. http://dx.doi.org/10.1177/0018726707087783 
Arthur, M. B., Hall, D. T., \& Lawrence, B. S. (1989). Generating new directions in career theory. In M. B. Arthur, D. T. Hall, \& B. S. Lawrence (Eds.), Handbook of career theory (pp. 7-25). Cambridge: Cambridge University Press.

Barley, S. R. (1989). Careers, identities, and institutions: the legacy of the Chicago School of Sociology. In M. B. Arthur, D. T. Hall, \& B. S. Lawrence (Eds.), Handbook of career theory (pp. 41-65). Cambridge: Cambridge University Press.

Becker, H. S. (1951). The professional dance musician and his audience. The American Journal of Sociology, 57(2), 136-144. http://dx.doi.org/10.1086/220913

Becker, H. S. (1997). A história de vida e o mosaico científico. In H. S. Becker, Métodos de pesquisa em ciências sociais (pp. 101-116). São Paulo: Editora Hucitec.

Becker, H. S. (2008). Outsiders: estudos de sociologia do desvio. Rio de Janeiro: Zahar.

Boylstein, C., \& Maggard, S. R. (2013). Small-scale marijuana growing: deviant careers as serious leisure. Humboldt Journal of Social Relations, 35, 52-70. Retrieved from http://www.jstor.org/stable/humjsocrel.35.52

Bruner, J. (1991). The narrative construction of reality. Critical Inquiry, 18(1), 1-20. http://dx.doi.org/10.1086/448619

Bucher, R., \& Strauss, A. (1961). Professions in process. American Journal of Sociology, 66(4), 325334. http://dx.doi.org/10.1086/222898

Burrow, R., Smith, J., \& Yakinthou, C. (2015). 'Yes chef': life at the vanguard of culinary excellence. Work, Employment and Society, 29(1), 673-681. http://dx.doi.org/10.1177/0950017014563103

Chudzikowski, K., \& Mayrhofer, W. (2011). In search of the blue flower? Grand social theories and career research: the case of Bourdieu's theory of practice. Human Relations, 64(1), 19-36. http://dx.doi.org/10.1177/0018726710384291

Coupland, C. (2014, July). Embodiment careers for rugby players. Proceedings of EGOS Colloquium, Rotterdam, The Netherlands, 30.

DeLuca, G., Rocha-de-Oliveira, S., \& Chiesa, C. D. (2016). Projeto e metamorfose: contribuições de Gilberto Velho para os estudos sobre carreiras. Revista de Administração Contemporânea, 20(4), 458-476. Retrieved from http://www.scielo.br/pdf/rac/v20n4/1982-7849-rac-20-40458.pdf. https://dx.doi.org/10.1590/1982-7849rac2016140080

DeMello, M. (2000). Bodies of inscription: a cultural history of the modern tattoo community. Durham, NC: Duke University Press.

Denzin, N. K. (1984). Interpretando a vida de pessoas comuns: Sartre, Heidegger e Faulkner. Revista de Ciências Sociais, 27(1), 29-43.

Domecka, M., \& Mrozowicki, A. (2005, July). Professional biographies in transition: comparing experiences of workers and business people in post-socialist Poland. Proceedings of World Congress of the International Institute of Sociology, Stockholm, Sweden, 37.

Eikhof, D. R., \& York, C. (2016). 'It's a though drug to kick': a woman's career in broadcasting. Work, Employment \& Society, 30(1), 152-161. http://dx.doi.org/10.1177/0950017015601859

Ferreira, V. S. (2004). Do renascimento das marcas corporais em contextos de neotribalismo juvenil. In J. M. Pais, \& L. M. da S. Blass (Orgs.), Tribos urbanas: produção artística e identidades (pp. 71102). São Paulo: Annablume. 
Ferreira, V. S. (2012). Das belas-artes à arte de tatuar: dinâmicas recentes no mundo português da tatuagem. In M. I. M. Almeida \& J. M. Pais (Orgs.), Criatividade, juventude e novos horizontes profissionais (pp. 56-112). Rio de Janeiro: Zahar.

Fine, G. A. (1993). The sad demise, mysterious disappearance, and glorious triumph of symbolic $\begin{array}{lllll}\text { interactionism. Annual } & \text { Review } & \text { Sociology, } & 19, & \text { 61-87. }\end{array}$ http://dx.doi.org/10.1146/annurev.so.19.080193.000425

Grandjean, B. D. (1981). History and career in a bureaucratic labor market. American Journal of Sociology, 86(5), 1057-1092. http://dx.doi.org/10.1086/227354

Hall, D. T. (1996). Protean careers of the 21 st century. Academy of Management Perspectives, 10(4), 816. http://dx.doi.org/10.5465/AME.1996.3145315

Hardy, K., \& Sanders, T. (2015). The political economy of 'lap dancing': contested careers and women's work in the stripping industry. Work, Employment and Society, 29(1), 119-136. http://dx.doi.org/ $10.1177 / 0950017014554969$

Helin, J., Hernes, T., Hjorth, D., \& Holt, R. (2014). The Oxford handbook of process philosophy and organization studies. New York: Oxford University Press.

Herva, S. (1988). The genesis of Max Weber's verstehende soziologie. Acta Sociologica, 31(2), 143156. http://dx.doi.org/10.1177/000169938803100203

Hughes, E. C. (1937). Institutional office and the person. American Journal of Sociology, 43(3), 404413. http://dx.doi.org/10.1086/217711

Hughes, E. C. (1958). Men and their work. Chicago: The University of Chicago Press.

Inkson, K., Gunz, H., Ganesh, G., \& Roper, J. (2012). Boundaryless careers: bringing back boundaries. Organization Studies, 33(3), 323-340. http://dx.doi.org/10.1177/0170840611435600

Khapova, S. N., \& Arthur, M. B. (2011). Interdisciplinary approaches to contemporary career studies. Human Relations, 64(1), 3-17. http://dx.doi.org/10.1177/0018726710384294

Kosut, M. (2006). Mad artists and tattooed perverts: deviant discourse and the social construction of cultural categories. Deviant Behavior, 27(1), 73-95. http://dx.doi.org/10.1080/016396290950677

Lawrence, B. S. (2011). Careers, social context and interdisciplinary thinking. Human Relations, 64(1), 59-84. http://dx.doi.org/10.1177/0018726710384293

Maroto, M. L. (2011). Professionalizing body art: a marginalized occupational group's use of informal and formal strategies of control. Work and Occupations, 38(1), 1-138. http://dx.doi.org/10.1177/0730888410385402

Marques, T. (1997). O Brasil tatuado e outros mundos. Rio de Janeiro: Rocco.

Mayrhofer, W., Meyer, M., \& Steyrer, J. (2007). Contextual issues in the study of careers. In H. Gunz, \& M. Peiperl (Eds.), Handbook of career studies (pp. 215-240). California: Sage Publications.

Meisenhelder, T. (1977). An exploratory study of existing from criminal careers. Criminology, 15(3), 319-334. http://dx.doi.org/10.1111/j.1745-9125.1977.tb00069.x

Moore, C., Gunz, H., \& Hall, D. (2007). Tracing de historical roots of career theory in management and organization studies. In H. P. Gunz \& M. Peiperl (Eds.), Handbook of career studies (pp. 19-38). Thousand Oaks, CA: SAGE Publications. http://dx.doi.org/10.4135/9781412976107.n2

Oliveira, A. M. P. (2012). A tatuagem como profissão: um ofício tornado arte? (Dissertação de mestrado). Instituto de Ciências Sociais, Universidade de Lisboa, Lisboa, Portugal.

BAR, Rio de Janeiro, v. 13, n. 4, art. 3, e160081, Oct./Dec. 2016

www.anpad.org.br/bar (ल) Br 
Platman, K. (2004). Portfolio careers'and the search for flexibility in later life. Work, Employment \& Society, 18(3), 573-599. http://dx.doi.org/10.1177/0950017004045551

Projeto de Lei $s / n$. (2007). Dispõe sobre a prática de tatuagem e "piercing”. Retrieved September 22, 2013 , http://www.camara.gov.br/proposicoesWeb/prop_mostrarintegra;jsessionid=5CEB5D0A97E05 13CB5BA6C9C100FB6A6.node1?codteor=476238\&filename=Tramitacao-PL+1444/2007

Projeto de Lei n. 1444 de 2007. (2013). Dispõe sobre a prática de tatuagem e "piercing". Retrieved September 22, 2013, from http://www.camara.gov.br/proposicoesWeb/prop_mostrarintegra;jsessionid=5CEB5D0A97E05 13CB5BA6C9C100FB6A6.node1?codteor $=1096375 \&$ filename $=$ Tramitacao-PL+1444/2007

Resolução RDC $n^{o}$ 306, de 7 de dezembro de 2004. (2004). Dispõe sobre o regulamento técnico para o gerenciamento de resíduos de serviços de saúde. Retrieved from http://portal.anvisa.gov.br/documents/33880/2568070/res0306_07_12_2004.pdf/95eac678d441-4033-a5ab-f0276d56aaa6

Resolução RDC $n^{\circ}$ 55, de 6 de agosto de 2008. (2008). Dispõe sobre o registro de produtos utilizados no procedimento de pigmentação artificial permanente da pele. Retrieved from http://portal.anvisa.gov.br/documents/10181/2718376/RDC_55_2008_COMP.pdf/604e9357$83 \mathrm{cc}-4 \mathrm{~b} 0 \mathrm{e}-8247-\mathrm{f} 81 \mathrm{ce} 5538 \mathrm{~b} 9 \mathrm{~d}$

Riessman, C. K. (2000, April 20). Analysis of personal narratives. Retrieved from http://alumni.media.mit.edu/ brooks/storybiz/riessman.pdf

Riessman, C. K. (2005). Narrative analysis. In N. Kelly, C. Horrocks, K. Milnes, B. Roberts, \& D. Robinson (Eds.), Narrative, memory \& everyday life (pp. 1-7). Huddersfield, UK: University of Huddersfield.

Siebert, S., \& Wilson, F. (2013). All work and no pay: consequences of unpaid work in the creative $\begin{array}{llll}\text { industries. Work, Employment \& } & \text { 711-721. }\end{array}$ http://dx.doi.org/10.1177/0950017012474708

Silva, J. R. da, Balassiano, M., \& Silva, A. R. L. da (2014). Burocrata proteano: articulações de carreira em torno e além do setor público. Revista de Administração Contemporânea, 18(1), 1 19. https://dx.doi.org/10.1590/S1415-65552014000100002

Simmel, G. (2011). Ensaios sobre teoria da história. Rio de Janeiro: Contraponto.

Simpson, R., Hughes, J., Slutskaya, N., \& Balta, M. (2014). Sacrifice and distinction in dirty work: men's construction of meaning in the butcher trade. Work, Employment and Society, 28(5), 754770. http://dx.doi.org/10.1177/0950017013510759

Sullivan, S. E., \& Baruch, Y. (2009). Advances in career theory and research: a critical revieu and agenda for future exploration. Journal of Management, 35(6), 1542-1571. http://dx.doi.org/10.1177/0149206309350082

Timming, A. R. (2011). What do tattoo artists know about HRM? Recruitment and selection in the body art sector. Employee Relations, 33(5), 570-584. http://dx.doi.org/10.1108/01425451111153916

Timming, A. R. (2015). Visible tattoos in the service sector: a new challenge to recruitment and $\begin{array}{llll}\text { selection. Work, } \quad \text { Employment } & \text { 60 }\end{array}$ http://dx.doi.org/10.1177/0950017014528402

Umney, C., \& Kretsos, L. (2013). Creative labour and collective interaction: the working lives of young jazz musicians in London. Work, Employment and Society, 28(4), 571-588. http://dx.doi.org/10.1177/0950017013491452 
Van Maanen, J. (2015). The present of things past: ethnography and career studies. Human Relations, 68(1), 35-53. http://dx.doi.org/10.1177/0018726714552287

Velho, G. (2006). Subjetividade e sociedade: uma experiência de geração (4a ed.). Rio de Janeiro: Jorge Zahar Ed.

\section{Authors' Profiles}

Gabriela DeLuca

EA/UFRGS, Rua Washington Luiz, 855, sala 324, 90010-460, Porto Alegre, RS, Brazil. E-mail address: deluca.gabi@gmail.com

Sidinei Rocha-de-Oliveira

EA/UFRGS, Rua Washington Luiz, 855, sala 324, 90010-460, Porto Alegre, RS, Brazil. E-mail address: sidroliveira@hotmail.com 